ALGIMANTAS ČESNULEVIČIUS, LORETA ŠUTINIENE்,

Accepted: 15.04.2019

VIGILIJA KRIKŠČIŪNINË, RIMA SVILIENE்,

NERINGA MAČIULEVIČIŪTĖ-TURIENE, ARTŪRAS BAUTRĖNAS,

GIEDRE BECONYTE், DONATAS OVODAS, LINAS BEVAINIS

Vilnius University, Faculty of Chemistry and Geosciences,

Department of Cartography and Geoinformatics

Vilnius, Lithuania

algimantas.cesnulevicius@gf.vu.It, loreta.sutiniene@gf.vu.lt,

vigilija.kriksciuniene@gf.vu.It, rima.sviliene@gf.vu.It,

neringa.maciuleviciute@gf.vu.It, arturas.bautrenas@gf.vu.lt,

giedre.beconyte@gf.vu.It, ovodas@gmail.com, linas.bevainis@gf.vu.It

\title{
The structure of Volume III of the National Atlas of Lithuania and techniques of cartographic visualization
}

\begin{abstract}
National atlases provide comprehensive information about nature, population, social and economic situation of the country. In 2017 the process of compiling and publishing the National Atlas of Lithuania (Lietuvos Nationalinis Atlasas) was finished. The goal of the authors is: in the context of the whole National Atlas to present a thorough analysis of the structure of content and cartographic visualization methods of Volume III. This volume focusses on social and economic phenomena in Lithuania. The authors discuss the principles of compiling the whole National Atlas of Lithuania and presents its structure in a concise manner. Following the classification of traditional mapping methods, specific examples of mapping in Volume III are presented, advantages of mapping techniques are discussed and the structural analysis of mapping methods is also conducted. The conclusions and the discussion part present the problems encountered while compiling Volume III as well as solutions to them.
\end{abstract}

Keywords: national atlas, social and economic phenomena, structure of atlas, mapping methods

\section{Introduction}

The majority of world countries publish national atlases, that is, representative cartographic works, which present a comprehensive characteristic of countries in their present territories. Many countries have published a number of editions of atlases, which allows actualising and updating information presented in publications of encyclopaedic character. Lithuania has looked forward to such a publication for almost a hundred years. It is true that Lithuanian geographers, soil scientists, geomorphologists, geologists, hydrologists prepared the first few cartographic works, which described separate components or peculiarities of the nature in the country as early as the interim period.
However, the available human resources, time and funds of that time were not enough for preparing one integral publication, i.e. an atlas. Atlas of Geography for gymnasium, compiled by Peliksas Šinkūnas and published by the Lithuanian polygraphic company in 1938, was a considerable achievement in the interwar period. This was the first cartographic publication of larger volume for schools, where the maps were made by well-known specialists of that time.

On the initiative of Professor Vaclovas Chomskis, the Laboratory of Cartography was established in the Faculty of Natural Sciences of Vilnius University in the 1960s. Its staff members carried out analytical spatial research on natural, demographic, social and economic 
phenomena and made a big number of complex thematic maps. The goal of all these activities was to compile and to publish a complex (national) atlas (R. Bugorevičienè, 1999; A. Pilipaitis, 1999).

The authors of the maps of the National Atlas had a goal to create a clear, integral and memorable spatial image of mapped phenomena and processes, which reflected the development of the country at the turn of two centuries. The maps in the Atlas were characterised by comprehensiveness and complexity of the mapped phenomena and were drawn up on the basis of the conducted multidimensional scientific research, the implemented analytical projects and the statistical data collected by various institutions (A. Pilipaitis, 2008; G. Beconytè, 1999, 2001; A. Česnulevičius, 2008; A. Česnulevičius, G. Beconytè, 2006; D. Valiukas et al., 2015).

\section{The historical overview of compiling Lithuanian atlases}

The first National Atlas of Lithuania (Lietuwos Nationalinis Atlasas) which met the criteria for a national atlas, was prepared in the period of 2014-2017. The Atlas of Lithuanian SSR, which was published in 1980 , only partially complied with the requirements for national atlases. In addition, the information presented in that atlas became out of data over 37 years. Lithuania underwent essential geopolitical, economic and social changes over that period and they changed the status of the country.

The initiative to publish the new national atlas emerged in the 1980s, when Lithuania was still incorporated into the USSR. The structure of the future atlas was foreseen, the data needed for drawing up the maps were collected and the authorship sketches of the maps were prepared. Due to political transformations, the atlas was not published as it had been planned. Later, after the country went through the changes in the economic and social structure, the previously made maps lost their relevance. However, the idea to compile and publish a fundamental cartographic work, which would reflect the country's political, economic, social, cultural and historical development and the existence of the Lithuanian nation was never abandoned (P. Gaučas, J. Milius, 1999).
The initiators of the National Atlas of Lithuania include geographers, natural scientists, historians, economists, sociologists working in Lithuanian research institutions and specialists from other fields. The idea to compile the $\mathrm{Na}$ tional Atlas of Lithuania originated in Vilnius University and its implementation united specialists from the Institute of Botany, the Institute of Ecology, the Institute of Geology, the Institute of Geography, the Lithuanian Institute of History, the Institute of Forestry, the Institute of Social Sciences, the Institute of Agriculture, the Geological Survey of Lithuania, Vilnius Gediminas Technical University and other research, management and industrial institutions. In 2005 the scientific editorial college was established and its members determined the main conception of the Atlas and made decisions about the content of its chapters and specific maps.

Developing the conception of the National Atlas and its content, making decisions about graphic presentation of maps and their editorial forms, the compilers aimed to create a cartographic publication, which would satisfy the needs of as a wide group of its potential users as possible. Attaining this goal, a homogenous integral publication was compiled, which consists of thematic volumes that focus on the territory of the Lithuanian state and its development, its situation in the European and global context, the country's nature and history as well as economic and social development.

The maps of the Atlas are divided into thematic chapters comprising a homogenous collection and consistently reveal the depth of the analysed themes. Moreover, an attempt was made to retain the volume of all the parts of the Atlas and their chapters the same.

\section{The general structure of the National Atlas of Lithuania}

The initial programme of the National Atlas provided for 4 volumes, which include the following parts:

Lithuania in Europe and the world, nature and landscapes (Volume I),

Historical development of Lithuania (Volume II), Economic development of Lithuania (Volume III),

Social development of Lithuania (Volume IV). After the first volume of the Atlas was pre- 
pared and published, it was decided to join the volumes on the economic development and the social development compiling one volume that would focus on territorial administrative division, population, social situation and development, economic situation and development.

The main maps of the Atlas are published at the scale $1: 1,000,000$. This is a scale, which allows detailed mapping of phenomena for all the territory of Lithuania. Generalized, more summarized phenomena and processes are mapped applying smaller scales $(1: 1,500,000$, $1: 2,000,000$ and $1: 4,000,000)$. The common-geographical background (hydrographic and road network, settlements, political and administrative borders) of maps is linked to the scales of specific maps, that is, they have a relevant level of detail (degree of generalization), which allows appropriate presentation of the mapped phenomena and processes. The borders of municipalities were chosen as basis for administrative division of the country mapping the borders of counties together. Historical maps represent borders of administrative division (lands, voivodships, counties, vicinities) of the respected period.

Every chapter of the Atlas begins with a short description of the theme. This is an introductory part of the chapter, which enables an user to better understand the analysed theme. Textual information is also presented in separate maps.

The unified structure is foreseen for all the parts of the National Atlas of Lithuania and it embraces:

1. Preface to the volume of the atlas,

2. Introduction of the volume,

3. General legend of the volume of the atlas,

4. Explanatory texts to the chapters of the volume,

5. Specific thematic maps,

6. Explanatory texts in English.

The content of a specific theme was disclosed applying the following consistency: a complex map of a theme $(1: 1,000,000) \rightarrow$ partial maps of a theme $(1: 1,500,000,1: 2,000,000) \rightarrow$ elementary maps of a theme $(1: 2,500,000,1: 3,000,000$, $1: 4,000,000)$. The content of a theme was revealed in 4-16 maps (1-4 sheets).

The maps of the National Atlas of Lithuania were drawn up employing 10 methods of cartographic visualization, such as choropleth, isochromatic, isoline, cartograms, cartodiagrams, localized diagrams, signs, linear signs, areal and linear cartodiagrams. Moreover, to ensure more comprehensive representation of phenomena, additional techniques of information representation were used: cross-sections, tables, diagrams, photo images and schemes (table 1).

Table 1. Methods of cartographic visualization of Lithuanian national atlas maps

\begin{tabular}{|c|c|c|c|}
\hline \multirow{2}{*}{$\begin{array}{l}\text { Visualization } \\
\text { method }\end{array}$} & \multicolumn{3}{|c|}{ Number of maps } \\
\hline & $\begin{array}{c}\text { First } \\
\text { volume }\end{array}$ & $\begin{array}{l}\text { Second } \\
\text { volume }\end{array}$ & $\begin{array}{c}\text { Third } \\
\text { volume }\end{array}$ \\
\hline Signs & 51 & 68 & 20 \\
\hline Linear signs & 38 & 47 & 14 \\
\hline Cartogram & 52 & 120 & 171 \\
\hline Cartodiagram & 26 & 43 & 143 \\
\hline $\begin{array}{l}\text { Localized } \\
\text { cartodiagram }\end{array}$ & 6 & 22 & 10 \\
\hline Linear cartodiagram & 9 & 31 & 1 \\
\hline Choropleth & 78 & 13 & 1 \\
\hline Isochromatic & 69 & 0 & 0 \\
\hline Isolines & 55 & 0 & 1 \\
\hline Areal & 47 & 39 & 1 \\
\hline Cross-sections & 3 & 0 & 0 \\
\hline Tables & 14 & 1 & 1 \\
\hline Diagrams & 23 & 17 & 90 \\
\hline Photo images & 4 & 3 & 5 \\
\hline Schemes & 0 & 0 & 1 \\
\hline
\end{tabular}

\section{Volume III of the National Atlas of Lithuania: the structure and mapping techniques}

Volume III of the National Atlas of Lithuania (fig. 1) reflects political, economic, social, cultural and historical changes that occurred at the turn of the 20st- 21st centuries. The Atlas consists of six large chapters that illustrate the development of the administrative division at the end of the 20th century - the beginning of 


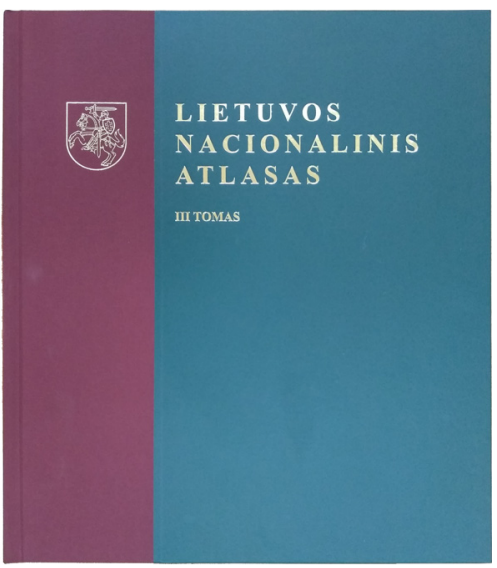

Fig. 1. Cover of Volume III of the National Atlas of Lithuania

the 21st century; dynamics of population, its national structure, professed religions and prevailing political attitudes; social situation of the population in the country and its development in recent decades; economic situation of the country, development of its agriculture and forestry; excavation of mineral resources and developed industries; the national transport system, transport of cargo and passengers, forms and volumes of communications services. A chapter consists of the sets of maps in separate themes that reflect the structure of mapped phenomena and their developments. Such a principle enabled the authors of the maps to comprehensively reveal the essence of the phenomena and processes, to visually present their spatial distribution, territorial regularities and changes.

The section representing the development of territorial-administrative division of the country is the smallest in its volume. It takes one chapter, which contains a map of administrative division of the country in 2016 and the development of the country's administrative division since 1940. The chapter also presents topographic maps of Lithuanian cities and more important towns: Vilnius, Kaunas, Šiauliai, Panevėžys (scale 1:70,000), Klaipėda, Palanga (scale 1:60,000), Neringa (scale 1:120,000), Alytus, Marijampolè, Utena, Telšiai, Tauragè, Druskininkai, Visaginas and Birštonas (scale 1:50,000).

The second part of the Atlas (Population, social situation and development) consists of two chapters: "Population" and "Social situation

Table 2. Methods of mapping and map scales of third volume of the National Atlas of Lithuania

\begin{tabular}{|c|c|c|c|}
\hline Chapter & $\begin{array}{l}\text { Number } \\
\text { of maps }\end{array}$ & Scale & Main mapping methods \\
\hline $\begin{array}{l}\text { Administrative division } \\
\text { of the state }\end{array}$ & 20 & $\begin{array}{c}1: 50,000,1: 60,000,1: 70,000 \\
1: 12,0000,1: 1,000,000,1: 2,000,000\end{array}$ & $\begin{array}{l}\text { Signs, linear signs, areal, } \\
\text { cartogram }\end{array}$ \\
\hline Population & 40 & $\begin{array}{l}1: 1,000,000,1: 1,250,000 \\
1: 1,500,000,1: 2,000,000 \\
1: 2,500,000,1: 4,500,000\end{array}$ & $\begin{array}{l}\text { Signs, linear signs, areal, } \\
\text { choropleth, isochromatic, } \\
\text { cartodiagram }\end{array}$ \\
\hline $\begin{array}{l}\text { Social state and develop- } \\
\text { ment }\end{array}$ & 65 & $\begin{array}{c}1: 90,000,1: 100,000,1: 1,000,000 \\
1: 1,250,000,1: 1,500,000 \\
1: 2,000,000,1: 2,500,000\end{array}$ & $\begin{array}{l}\text { Signs, linear signs, areal, } \\
\text { choropleth, isochromatic, } \\
\text { cartodiagram, isolines }\end{array}$ \\
\hline Agriculture and forestry & 59 & $\begin{array}{l}1: 1,000,000,1: 1,250,000 \\
1: 1,500,000,1: 2,000,000 \\
1: 2,500,000,1: 4,000,000\end{array}$ & $\begin{array}{l}\text { Signs, isochromatic, areal, } \\
\text { choropleth, cartodiagram }\end{array}$ \\
\hline $\begin{array}{l}\text { Natural resources and } \\
\text { industry }\end{array}$ & 23 & $\begin{array}{c}1: 1,000,000,1: 1,500,000 \\
1: 2,000,000,1: 20,000,000 \\
1: 78,000,000\end{array}$ & $\begin{array}{l}\text { Signs, linear signs, areal, } \\
\text { choropleth, cartodiagram }\end{array}$ \\
\hline $\begin{array}{l}\text { Transport and } \\
\text { communication }\end{array}$ & 26 & $\begin{array}{c}1: 1,000,000,1: 1,500,000 \\
1: 2,000,000,1: 2,500,000 \\
1: 4,000,000\end{array}$ & $\begin{array}{l}\text { Signs, linear signs, areal, } \\
\text { choropleth, isochromatic, } \\
\text { cartodiagram }\end{array}$ \\
\hline
\end{tabular}




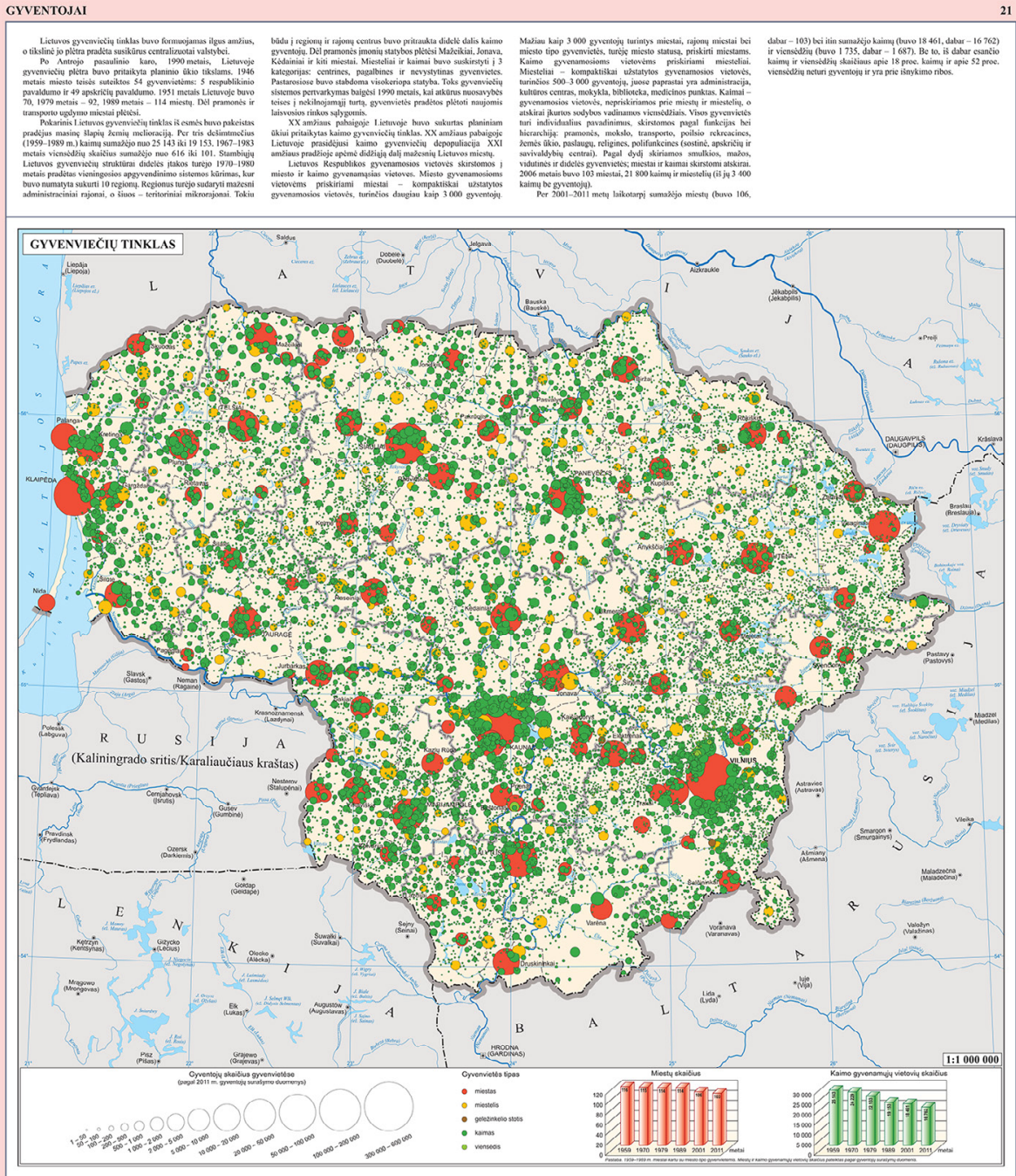

Fig 2. The settlements network - their types and number of inhabitants, with explanatory text (reduced - original scale 1:1,000,000)

and development". The network of settlements (fig. 2), density of population and its dynamics, density of population in cities, natural decrease or increase in population, proportion of men and women and its dynamics, marriages, divorces, dynamics of number of families, numbers of children in families (fig. 3), the structure of the age of population and its changes, national composition of population, internal and external migration of population, religious communities and their distribution and dynamics of political views of population are mapped in this chapter. The total number of maps in this chapter equals 40 (table 2).

The next chapter in this part of Volume III introduces the mapped phenomena of (un)em- 


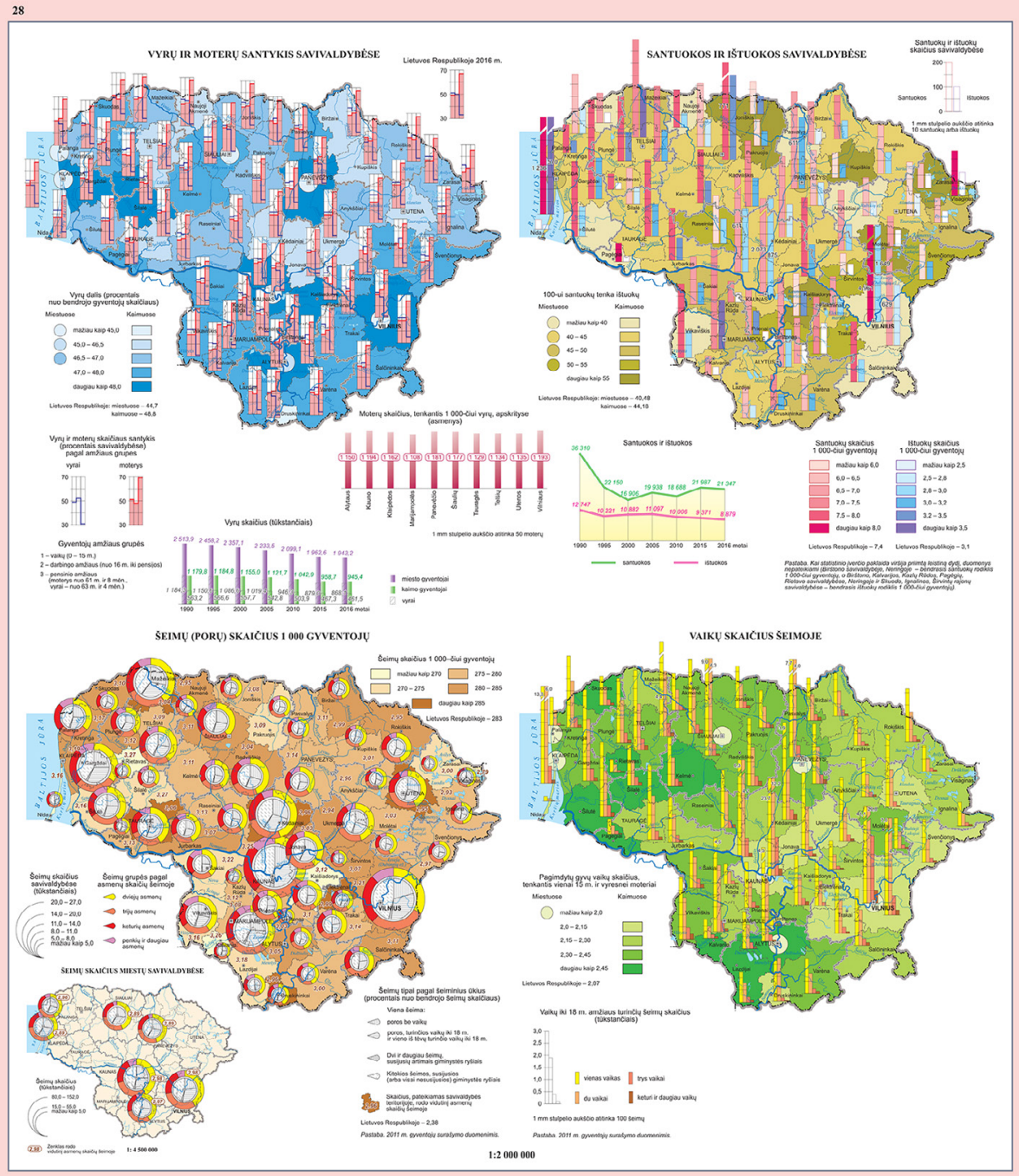

Fig. 3. Proportion of men and women, marriages and divorces, number of families, and number of children in families (reduced - original scale 1:2,000,000)

ployment of population, proportions between working and dependant people, sources of income, dynamics of wage rates, numbers of people in the social security system, social benefit receivers, stock of residential buildings in cities and rural settlements, phenomena of early childhood education and school children's education, dynamics of numbers of students in vocational schools, colleges and universities, population by educational levels, dynamics of cultural phenomena and their spatial distribution, spatial distribution of health care institutions, dynamics of numbers of patients, distribution of crime and its dynamics, financial and insu- 


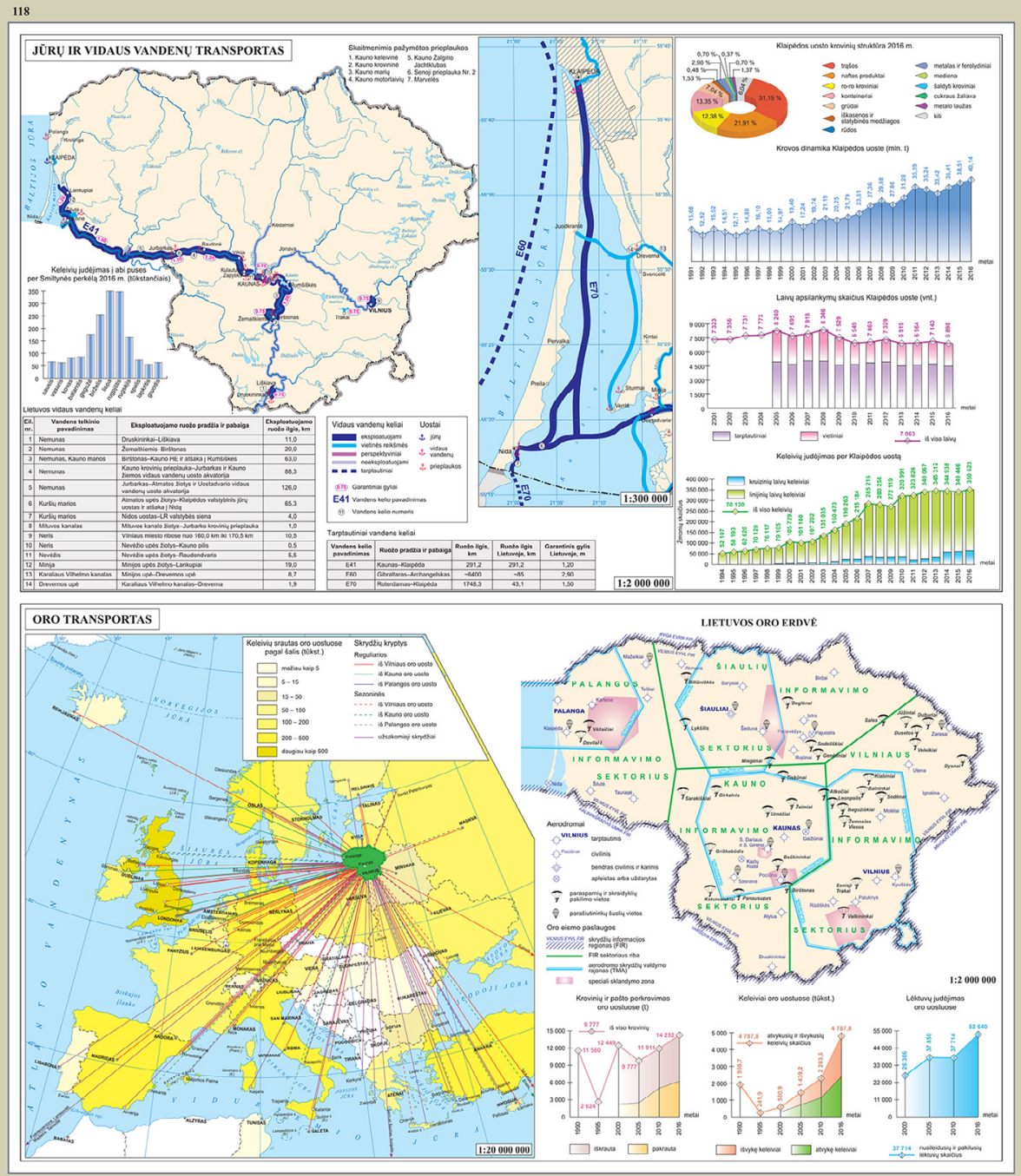

Fig 4. Maritime and inland waterway transport (above); air transport (below): international connections, airports and airfields (reduced - original scales 1:2,000,000, 1:300,000 and 1:20,000,000)

rance service institutions, development of volumes of their provided services, tourist sites, their distribution and attendance, flows of domestic and foreign tourists, territorial organisation of environmental protection and territorial development of investments to environmental protection. There are 65 maps in the chapter and the data on their scales is presented in table 2 .

The third part of the Atlas (Economic situation and development) consists of three chapters: "Agriculture and forestry", "Natural resource mining and industry" and "Transport and communications". The first chapter focuses on the 
general structure of utilised agricultural area and its dynamics, fertility of utilised agricultural area, structure of private agrarian holdings, energy supply of utilised agrarian holdings; crop structure, grain crops, technical crops, fodder crops, potato and vegetable areas and their dynamics; fertility of utilised land; development of ecological farms; total number of animals; numbers of cattle, pigs, sheep, goats, horses; numbers of rabbits, geese, duck; milk production; meat production; poultry; apiculture; revenue from agriculture; territorial organisation of forests; timber resources and timber purveyance; territorial organisation of hunting; territorial organisation of fishery; volumes of inland and sea fishery. There are 59 maps in the chapter.

The next chapter "Natural resource mining and industry" introduces the mapped mining of building materials, oil, peat and groundwater extraction; electricity production, electricity production from renewable sources; separate industries (manufacturing, wood, food, beverages, textiles, leather and fur); added value generated by industries; distribution and development of foreign investments; volumes of country's export and import. The chapter introduces 23 maps.

The third chapter "Transport and communications" presents the mapped road and pipeline network; numbers of passenger cars and their distribution; traffic volume on roads; distribution of road accidents; transport of passengers and cargo by automotive and railway vehicles; transportation by maritime, inland waterway and air transport (fig. 4); post offices; mobile telecommunications operators and coverage of their services; accessibility of internet services. The chapter has 28 maps and the structure of their scales is presented in table 2 .

The maps of Volume III of the National Atlas of Lithuania are drawn up using 9 techniques of cartographic visualization: choropleth, isopleth or isoline, cartodiagram, localized diagram, signs, linear signs, areal and linear diagram mapping methods. The isoline method is used to present the distribution of registered acts (crimes) in cities; relative quantitative values of different phenomena in municipalities of the country are presented in choropleth; dynamics of population density in municipalities - in cartodiagrams; localised diagrams mark the network of settlements; religious communities are pre- sented with graphic signs; linear signs show high voltage electricity transmission networks; recreational territories are visualized using areal method and traffic intensity is mapped applying linear diagrams. Moreover, structural schemes (the national system of education) are used as additional elements in the Atlas (table 2).

\section{Discussion}

Working on Volume III of the National Atlas of Lithuania, its compilers faced certain challenges. The majority of them were related to insufficient volume of available data, their nondetailed localisation, different criteria applied while collecting state statistical data and others. The main encountered challenges:

1. Data irregularities in terms of time. The data for some phenomena were collected episodically. The consecutive data year by year were not available.

2. Spatial irregularities of data. Some data were of local character and represented only several municipalities or counties.

3. Heterogeneity of data. 1 January 2008 a new statistical classification of economic activities entered into force, which is in line with Regulation (EC) No. 1893/2006 of the European Parliament and of the Council of $20 \mathrm{De}$ cember 2006 establishing the statistical classification of economic activities. This introduced essential changes in the data collection accumulated after 2008.

4. Statistical indicators of collected data. In 2008 the indicators of collected statistical data were also changed. Since then physical quantities (units, tonnes, $\mathrm{m}^{3}$ and others) have been frequently replaced by monetary values (monetary value of production or monetary value of sold production). Due to movements in prices it was complicated to evaluate the physical volumes of production.

5. Data confidentiality. Some data were unavailable because they fell within the category of confidential data.

6 . Identification of physical location of objects. A number of enterprises and companies tend to present location of their headquarters only. In the meantime, production is carried out in other locations, which are not included into the data accumulated by Statistics Lithuania. This is particularly characteristic of enterprises that 
specialise in mining, manufacturing industries and in processing of agricultural products.

The compilers of the Atlas managed to cope with all the above-mentioned and other undefined problems. It is also symbolic that Volume III of the National Atlas of Lithuania was published on the eve of the Centennial of the Restored State of Lithuania. Like the previous volumes, this issue is expected to have the place it deserves among other fundamental scientific works and to contribute to scientific, social and cultural analysis of the country, to deepen awareness of its society as well as to be useful to everyone who seeks knowledge.

\section{Conclusions}

The National Atlas of Lithuania is an unique cartographic publication, which provides a comprehensive presentation of the nature, society of the country, its social and historical development. This is a publication of encyclopaedic

\section{Literature}

Beconytė G., 1999, Information modeling and data-bases in cartographic project. In: A. Česnulevičius (ed.), Thematical cartography of Lithuania after independent restores. Vilnius: Vilnius University, pp. $139-147$.

Beconytè G., 2001, Requirements in thematic cartography. "Geography" Vol. 37, no. 2, pp. 47-53.

Bugorevičienè R., 1999, The works of Lithuania thematical mapping in the laboratory of Cartography of Vilnius University. In: A. Česnulevičius (ed.), Thematical cartography of Lithuania after independent restores. Vilnius: Vilnius University, pp. 158-162.

Česnulevičius A., 2008, Ecological map of Lithuania: subject, cartographical methods, perspectives.. "Geography" Vol. 44, no. 1, pp. 38-44.

Česnulevičius A., Beconytė G., 2006, Lithuanian historical maps: periods, methods, accuracy and perspectives. "e-Perimetron" Vol. 1 , no. 4, pp. 253-261, http://www.e-perimetron.org/Vol_1_4/Vol1_4.htm. character, which presents fundamental knowledge of Lithuania.

Diverse information, which is available in the maps of the Atlas, allows their users to conduct a complex evaluation of phenomena and processes that occur in the country as well contributes to building an integral holistic and synthetic view of Lithuania.

The maps of the National Atlas of Lithuania are compiled employing various mapping techniques and the extent of their application in different volumes of the Atlas also differs. The maps drawn using choropleth (70 maps), isochromatic (67 maps), isoline (56 maps) and geometric signs (52 maps) methods prevail in Volume I. The frequency of mapping methods in Volume II is as follows: choropleth (117 maps), maps of geometric signs (69 maps) and those of linear signs (45 maps). Choropleth (174 maps) and cartodiagrams (136 maps) are most frequently used in the maps of Volume III. Other mapping techniques are rarely employed in the maps of this volume.

Gaučas P., Milius J., 1999, Complex Atlas of the Republic of Lithuania: problems of its preparation in Soviet times and future perspectives. In: A. Česnulevičius (ed.), Thematical cartography of Lithuania after independent restores. Vilnius: Vilnius University, pp. 163-172.

Pilipaitis A., 1999, Progressives and irregular aspects of development of the thematic cartography in Lithuania. In: A. Česnulevičius (ed.), Thematical cartography of Lithuania after independent restores. Vilnius: Vilnius University, pp. 4-9.

Pilipaitis A., 2008, Relations in the map informative system. "Geography" Vol. 44, no. 2, pp. 73-74.

Valiukas D., Galvonaitè A., Česnulevičius A., 2015, Methodology of Lithuanian climate atlas mapping. "Geodesy and Cartography" Vol. 64 no. 1, pp. 101-112. DOI: https://doi.org/10.1515/geocart-2015-0008. 